\title{
Izaak I Komnen (1007-1060). Wódz, buntownik, cesarz - w poszukiwaniu jego doktryny wojennej?
}

Izaak Komnen (1007-1060) był pierwszym przedstawicielem swojej rodziny, który zasiadł na cesarskim tronie w Konstantynopolu. Ten człowiek wychowany przez cesarza Bazylego II (976-1025) podjął podczas niezwykle krótkiego panowania próbę naprawy błędów swoich poprzedników, którzy pod koniec dynastii macedońskiej uczynili kraj Rzymian słabym militarnie. Nie byłoby to możliwe bez gruntownego wykształcenia wojskowego, poszerzonego o doświadczenie empiryczne, które Izaak nabył w latach swojej służby na różnych szczeblach bizantyńskiej armii. Czy zatem możliwe jest zarysowanie doktryny wojennej, która przyświecała temu człowiekowi na różnych etapach jego służby, a której finałem była cesarska purpura? Próbę odpowiedzi na to pytanie podejmę w niniejszym artykule. Punktem wyjścia będą prace wybranych bizantyńskich dziejopisów z XI i XII wieku, które związane są z opisem panowania tego Komnena, ponadto pieczęcie, jak również numizmaty bite przez tego basileusa.

Nim jednak rozpocznę swój wywód na temat Izaaka, warto w tym miejscu przytoczyć encyklopedyczną definicję pojęcia doktryny wojskowej, by później zestawić to z informacjami ze źródeł: ,przyjęty w państwie (koalicji państw) w danym czasie zespół poglądów na charakter wojny, na przygotowanie do niej kraju i sił zbrojnych, a także na sposób jej prowadzenia"'. Doktryna wojenna wiązana jest również z edukacją przyszłych dowódców, która nie może być w żaden sposób dogmatyczna, a raczej powinna być elastyczna i przystająca do zagrożeń, co współcześnie skutecz-

\footnotetext{
Dr hab. Marcin Böhm, prof. UO, Instytut Historii Uniwersytetu Opolskiego; email: mabohm@wp.pl; ORCID 0000-0002-5393-3176.

2 Encyklopedia PWN, w: https://encyklopedia.pwn.pl/haslo/doktryna-wojenna;3893480.html (dostęp: 10.10.2019).
} 
nie rozwija w swoich szkołach wojskowych wiele państw (w tym Izrael, Rosja i USA). Co zatem wiadomo pewnego na temat edukacji wojskowej naszego bohatera?

Izaak był wychowywany po śmierci swego ojca Manuela Erotikosa przez cesarza Bazylego II. Wedle słów Bryenniosa Bazyli skierował go wraz z jego bratem Janem na naukę do klasztoru Stoudios, gdzie cesarz zapewnił młodym arystokratom także nauczycieli sposobu prowadzenia wojny i taktyki wojskowej ${ }^{3}$. Co ciekawe, zdaniem Jana Zonarasa nie był Izaak dobrze zaznajomiony z literami, lecz uczył się ich i był otwarty na tych, którzy je pielęgnowali ${ }^{4}$. Dzięki bliskości z cesarskim dworem i zdobytemu wykształceniu wojskowemu pomiędzy 1042 a 1045 rokiem wstąpił do cesarskiej Hetaireii, co później otworzyło mu drogę do służby wojskowej na prowincji na najwyższych stanowiskach ${ }^{5}$. Zasłynął jako przykład wodza biegłego w sztuce wojennej ${ }^{6}$. Na pograniczu Bizancjum doszedł do rangi stratopedarchy Wschodu, magistra vestesa. Te tytuły dzierżył w 1055 $\mathrm{roku}^{7}$. Z tego okresu jego życia pochodzą jeszcze dwie pieczęcie, z których wynika, że przez pewien czas był on katepanem i patrycjuszem Iberii, jak również protospatariuszem oraz katepanem Vaspurakanu ${ }^{8}$. Na jednej ze swoich pieczęci Izaak przedstawiał się także jako $d u k s^{9}$.

Dzięki informacjom pochodzącym z pieczęci jesteśmy w stanie prześledzić wczesny etap kariery zawodowej Izaaka w niepełnym stopniu. Nie

3 Por. Nicephore Bryennios, Historiarum libri quattuor I 1, 75, 15-22; K. Varzos, Genealogía ton Komninón, t. A, Thessaloniki 1984, s. 39; V. Stanković, Komnini u Carigradu (1057-1185). Evolucija jedne vladarske porodice, Beograd 2006, s. 9; J.-Cl. Cheynet, Pouvoir et contestations à Byzance (963-1210), Paris 1996, s. 341; V.S Šandrovskaja, Isaak Komnin - pravitel' Iverii, „Istoriko-filologičeskij Zurnal” 4 (1983) s. 114.

4 Por. Ioannes Zonaras, Epitome Historiarum libri XIII-XVIII, CSHB 49, ed. T. Buttner-Wobst, Leipzig 1897, XVIII 7, 9, 674.

5 Por. Nicephore Bryennios, Historiarum libri quattuor I 2, 77, 5-10.

6 Por. Constantinus Manasses, Breviarium chronicum, t. 1, ed. O. Lampsidis, Athens 1996 I 6254-6260, 339.

7 Por. Ioannes Scylitzes, Synopsis Historiarum, ed. I. Thurn, Berlin-New York 1973, 1, 479; Michael Glycas, Annales, ed. I. Bekker, Bonn 1836 14, 603; Varzos, Genealogía ton Komninón, s. 41; J.-Cl. Cheynet, L'iconographie des sceaux des Comnènes, w: Siegel und Siegler: Akten des 8. Internationalen Symposiums für Byzantinische Sigillographie, ed. Cl. Ludwig, Frankfurt a. M. 2005, s. 55, nr 8; J.-CL. Cheynet, Par St Georges, par St Michel, Travaux et Mémoires 14 (2002) s. 122; S. Wierzbiński, U boku bazyleusa. Frankowie i Waregowie w cesarstwie bizantyńskim w XI w., Łódź 2019, s. 295-296.

8 Por. Cheynet, L'iconographie, s. 55, nr 5 i 6; Cheynet, Pouvoir, s. 341; Šandrovskaja, Isaak Komnin, s. 111-113.

9 Por. Cheynet, L'iconographie, s. 55, nr 7. 
wiemy, kiedy został dokładnie skierowany do temów zamieszkanych przez Armeńczyków (Vaspurakan) czy Gruzinów (Iberia) oraz co tam osiągnął ${ }^{10}$. Obie te prowincje powstały jako wynik wcześniejszych działań wojennych Bazylego II i Konstantyna IX Monomacha, dlatego jako świeży nabytek cesarstwa wymagały szczególnej uwagi ${ }^{11}$. Od 1045 roku zagrożenie dla tych ziem ze strony Seldżuków stało się już oczywiste i próbowali oni nawet zdobyć Mantzikert (w 1054 roku) ${ }^{12}$. Basileus Konstantyn Monomach, niejako odchodząc od polityki prowadzonej wcześniej przez Bazylego II, według relacji Skylitzesa około 1053 roku zlikwidował liczącą 50000 ludzi armię Iberii, w której służbę zamienił na płacenie podatków nałożonych na ten region $^{13}$. Nie wiemy, gdzie w tym momencie przebywał i co robił Izaak. Możemy jedynie spekulować, iż dopiero po 1053 roku został on stratopedarchą Wschodu, a wcześniej zapewne zajmował się z polecenia Konstantyna IX demobilizacją oddziałów składających się z Gruzinów i Armeńczyków. Niejako zdają się potwierdzać te przepuszczenia słowa Glykasa i Skylitzesa, którzy zgodnie stwierdzili, że po ponownym objęciu cesarskiego tronu przez młodszą siostrę Zoe, Teodorę w 1055 roku odsunęła ona od dowództwa nad armią na Wschodzie Izaaka, zastępując go swoim eunuchem Teodorem ${ }^{14}$.

Kolejnym etapem życia wojskowego Izaaka był udział w rebelii z 1057 roku przeciwko następcy Teodory, Michałowi VI Starszemu. Przed jej wybuchem Izaak stanął na czele delegacji bizantyńskich wodzów z Azji Mniejszej, którzy od nowego basileusa domagali się tytułu proedrosa dla Komnena i Katakalona Kekaumena, jak również liczyli na wsparcie pieniężne z jego strony ${ }^{15}$. Ich żądania zostały odrzucone przez basileusa, który dodatkowo obraził przywódców delegacji, zarzucając im tchórzostwo, korupcje i złe

10 V.S. Šandrovskaja sugeruje, że miało to miejsce pomiędzy 1028 a 1038 rokiem. Por. Šandrovskaja, Isaak Komnin, s. 116.

11 Por. Kekaumenos, Sovety i rasskazy Kekavmena: Sočinenie vizantijskogo polkovodca XI veka, ed. G.G. Litavrin, Moscow 2003, § 81, s. 282; Ioannes Scylitzes, Synopsis Historiarum 355-356 i 8, 434-439.

12 Por. Michael Attaliates, Historia, ed. A. Kaldellis - D. Krallis, London 2012, VIII 76-82; Ioannes Scylitzes, Synopsis Historiarum 9, 442-12, 449.

13 Por. Ioannes Scylitzes, Synopsis Historiarum 29, 476; W. Treadgold, Byzantium and Its Army, 284-1081, Stanford 1995, s. 215-216.

14 Por. Ioannes Scylitzes, Synopsis Historiarum 1, 479; Michael Glycas, Annales 13-14, 599; A.S. Mochov, Komandnyi sostav vizantijskoi armii v 1055-1057 gg., ADSV 33 (2002) s. 110-111; Cheynet, Pouvoir, s. 341; A. Kaldellis, Streams of Gold, Rivers of Blood: The Rise and Fall of Byzantium, 955 A.D. to the First Crusade, Oxford 2017, s. 216.

15 Por. Ioannes Scylitzes, Synopsis Historiarum 2, 483; A.S. Mochov, Voyennaya politika Isaaka I Komnina, ,Nauchnyye vedomosti Belgorodskogo gosudarstvennogo uni- 
dowodzenie obroną Antiochii ${ }^{16}$. Cesarz miał według Lastiwertycza zagrozić, że owi dowódcy mają iść na wojnę przeciwko Persom (Seldżukom), aby zapobiec ich najazdom, a jeśli tego nie zrobią, odda żołd przeznaczony dla nich owym najeźdźcom i w ten sposób powstrzyma dalsze spustoszenie ziemi chrześcijan ${ }^{17}$. Również druga delegacja skierowana tym razem nie do basileusa, lecz do protosynkela Leona Paraspondyla została potraktowana w identyczny sposób jak pierwsza i pretensje wodzów małoazjatyckich odrzucono $^{18}$. Od tego momentu zawiedzeni ludzie ze środowiska Komnena przeszli w kierunku otwartego buntu. Izaak nie był początkowo jedynym potencjalnym kandydatem do purpury, mógł bowiem nim zostać Nikefor Brynnienios Starszy. Kandydaturę tego ostatniego zgubiło przejęcie przez niego pieniędzy przeznaczony na żołd dla żołnierzy, za co został pojmany i następnie oślepiony przez ludzi Michała $\mathrm{VI}^{19}$.

Na wieść o tych wydarzeniach buntownicy zgromadzili się w Gounarii znajdującej się w Paflagonii, skąd zaplanowali rozszerzyć swe działania na całą Azję Mniejszą ${ }^{20}$. Poczynania Katalona Kekaumena doprowadziły do tego, że uzurpatorem został Izaak Komnen, który opuścił swój domowy azyl w Kastamonie i skierował się do Gounarii ${ }^{21}$. Kekaumen zdobył dla Izaaka poparcie oddziałów najemników (Franków i Rusów), jak również wojsk z Koloneii, Chaldii, Sebasteii, Meliteny, Tefrikii, temu armeńskiego, łącznie około 10000 ludzi ${ }^{22}$. Na czele swojej nowej armii Izaak Komnen rozpoczął

versiteta. Ser., Istoriya. Ekonomika. Politologiya. Informatika” 120 (2012), s. 54; Y. Nezu, The Revolt of Isaakios Komnenos: Reconsideration, „Orient” 42 (2006) s. 53.

16 Por. Michael Psellos, Chronographie (976-1077), ed. E. Renauld, Paris 1928, t. II VII 3, 84-85; Constantinus Manasses, Breviarium chronicum 1, 6266-6270, 339; Ioannes Zonaras, Epitome Historiarum XVIII 1, 654; Michael Glycas, Annales 600, 5-12.

17 Por. Aristakes Lastivertsi, Historia, ed. R. Bedrosian, New York 1985, s. 119-120.

18 Por. Ioannes Scylitzes, Synopsis Historiarum 5, 486-487; Michael Attaliates, Historia XI 2, 96; M. Böhm, The Military Policy of Isaac Komnenos at the time of battle of Petroe (1057), „Open Political Science” 1 (2018) s. 137; Kaldellis, Streams, s. 217.

19 Por. Michael Attaliates, Historia XI 3, 96; Ioannes Scylitzes, Synopsis Historiarum 6, 488; K. Inoue, The Rebellion of Isaakios Komnenos and the Provincial Aristocratic Oikoi, „Byzantinoslavica” 54 (1993) s. 272-273.

20 Por. Michael Psellos, Chronographie II; VII 4, 85; Šandrovskaja, Isaak Komnin, s. 115.

21 Por. Ioannes Scylitzes, Synopsis Historiarum 6, 488-489; Böhm, The Military Policy, s. 138; Mochov, Komandnyi sostav vizantijskoi armii v 1055-1057, s. 115-116; Cheynet, Pouvoir, s. 340; E. Stănescu, Les réformes d'Isaac Comnène, RESEE 4 (1966) s. 39-40.

22 Por. Ioannes Scylitzes, Synopsis Historiarum 7, 490-492; Mokhov, Voyennaya politika, s. 52-53; Wierzbiński, U boku bazyleusa, s. 54 i 164; J. Haldon, Warfare, State and Society in the Byzantine World, 565-1204, London 2003, s. 119. 
powolny marsz w kierunku Niceii, starając się jak najdłużej odwlekać starcie zbrojne z wojskami wiernymi Michałowi VI. Działania te doprowadziły do masowych dezercji w siłach lojalistów ${ }^{23}$. Nicea również poddała się uzurpatorowi bez walki, dzięki czemu zyskał on solidny punkt obronny w pobliżu stolicy ${ }^{24}$. Cesarz przeciwko niemu rzucił oddziały Macedończyków, które wsparte zostały przez wojska pochodzące z temów Anatolikon i Charsianon, którymi dowodził eunuch Teodor ${ }^{25}$. Do finalnego starcia doszło pod Petroe/ Haides 20 sierpnia 1057 roku $^{26}$. Zwycięzcą w niej okazał się Izaak, który rozbił siły wierne Michałowi ${ }^{27}$. Następnie armia Izaaka udała się do Nikomedii, skąd chciał on prowadzić rozmowy z basileusem, który wysłał do niego trzech posłów, proponując mu adopcję i tytuł cezara ${ }^{28}$. Stało się jednak inaczej bowiem patriarcha Michał Cerulariusz przekonał Michała VI, aby ten abdykował na korzyść Komnena 31 sierpnia 1057 roku $^{29}$. Izaak wkroczył do stolicy 1 września i koronował się na cesarza ${ }^{30}$.

23 Por. Ioannes Scylitzes, Synopsis Historiarum 7, 492.

24 Por. Michael Attaliates, Historia XI 4, 96; Ioannes Scylitzes, Synopsis Historiarum 9, 494.

25 Por. Ioannes Scylitzes, Synopsis Historiarum 8, 493.

26 Por. J. Bonarek, Bizancjum w dobie bitwy pod Mantzikert, Kraków 2011, s. 47-48; J. Dudek, Pęknięte zwierciadło - kryzys i odbudowa wizerunku władcy bizantyńskiego od 1056 do ok. 1095 roku, Zielona Góra 2009, s. 51; M. Angold, The Byzantine Empire 1025-1204. A political history, London 1984, s. 50; B. Krsmanović, Uspon vojnog plemstva u Vizantii XI veka, Beograd 2001, s. 210-213; Mochov, Voyennaya politika, s. 55; Haldon, Warfare, s. 90; Kaldellis, Streams, s. 218.

27 Por. Michael Psellos, Chronographie II; VII 13-14, 90-91; Michael Attaliates, Historia XI 5-6, 99-100; Ioannes Scylitzes, Synopsis Historiarum 9-10, 494-496; Constantinus Manasses, Breviarium chronicum I 6285a-6285h, 340; Nezu, The Revolt of Isaakios, s. 43; Ioannes Zonaras, Epitome Historiarum XVIII 2, 660; Matteos Uṛhayetsi, Zhamanakagrut 'iwn-The Chronik of Matthew of Edessa, ed. A.E. Dostourian, New York 1993, s. 89; Cheynet, Pouvoir, s. 340.

28 Por. Ioannes Scylitzes, Synopsis Historiarum 11, 496; Michael Psellos, Chronographie II; VII 32, 102.

29 Por. Michael Attaliates, Historia XI 6-9, 100-106; Ioannes Scylitzes, Synopsis Historiarum 11-12, 496-500; Michael Psellos, Chronographie II; VII, 15-42, 91-110; Aristakes Lastivertsi, Historia, s. 131; J. Shepard, Isaac Comnenus Coronation Day, „Byzantinoslavica” 38 (1977) s. 22-30; Bonarek, Bizancjum w dobie, s. 48; Dudek, Pęknięte zwierciadto, s. 51-52; Angold, The Byzantine Empire, s. 50; Krsmanović, Uspon vojnog plemstva, s. 13-231; Varzos, Genealogía ton Komninón, s. 42; Mochov, Voyennaya politika, s. 55.

30 Por. A. Cutler - C.M. Brand, Isaac I Komnenos, w: Oxford Dictionary of Byzantium, t. 2, ed. A. Kazhdan, Oxford 1991, s. 1011-1012; Shepard, Isaac Comnenus, s. 22-30. 
Postawę Izaaka w dobie buntu przeciwko Michałowi VI trudno sklasyfikować jako przejaw jakiegoś szerszego planu czy realizacje jakieś doktryny wojennej. To Katalon Kekaumen był tym, który popchnął urażonego osobiście Izaaka do uzurpacji, zapewniając mu poparcie oddziałów wojskowych, które podstępem lub groźbą przeciągnął na stronę Komnena. Ten brak planu ze strony Izaaka widać szczególnie mocno w czasie marszu w kierunku Niceii, jak w samym starciu pod Petroe/Haides, gdzie miał on moment zwątpienia, który prawie skończył się jego ucieczką z pola bitwy $^{31}$. Podobnie należy interpretować jego nastawienie wobec posłów cesarza Michała. Wszystko to zmieniło się jednak po ustąpieniu z tronu starego basileusa, w czym wydatny udział miał patriarcha Konstantynopola. Od tego momentu Komnen przeszedł do bardziej zdecydowanych działań.

Izaak swoje panowanie zaczął od nagrodzenia swoich sojuszników, przy pomocy których doszedł do władzy, zarówno tych ze swojej wojskowej frakcji, jak i duchownych, w tym patriarchy ${ }^{32}$. Brat Jan otrzymał tytuł kuropalaty i dowódcy armii Zachodu ${ }^{33}$. Nowy basileus nagrodził także najemników znajdujących się na jego służbie ${ }^{34}$. Część towarzyszących mu oddziałów odesłał jednak później do Azji Mniejszej ${ }^{35}$. Ponadto nie zezwolił Armeńczykom i Gruzinom na opuszczenie zajmowanych przez nich ziem wchodzących w skład cesarstwa, jak również motywował ich dowódców wojskowych do bardziej zdecydowanego oporu przeciw zagrożeniom ${ }^{36}$. Seldżukowie w październiku 1057 roku zaatakowali Melitene, pod którą doszło do bitwy z Bizantyńczykami, przegranej przez tych ostatnich, co zaowocowało następnie zdobyciem tego miasta i rzezią tych jego mieszkańców, którzy nie zdążyli wcześniej uciec ${ }^{37}$. W kolejnych latach bizantyńska Armenia dalej była zagrożona ze strony tych Turków, którym siły cesarskie nie spieszyły się wydać walnej bitwy, a raczej przyjęto taktykę zmęczenia wroga, zmuszając go do oblężenia umocnionych punktów ${ }^{38}$. Być

31 Por. Böhm, The Military Policy, s. 140-141.

32 Por. Michael Attaliates, Historia XII 2, 108; Skylitzes Continuatus, He synecheia tes Chronographias tou Ioannou Skylitse, ed. E.Th. Tsolakes, Thessalonike 1968, 3-8, 103; Michael Glycas, Annales 1-8, 601.

33 Por. Nicephore Bryennios, Historiarum libri quattuor I 1, 79, 8-11; Ioannes Zonaras, Epitome Historiarum XVIII 4, 4, 666; Kaldellis, Streams, s. 220.

34 Por. Wierzbiński, U boku bazyleusa, s. 234.

35 Por. Michael Psellos, Chronographie II; VII 45, 111; Ioannes Zonaras, Epitome Historiarum XVIII 4, 4, 666.

36 Por. Michael Psellos, Chronographie II; VII 50, 113-114.

37 Por. Aristakes Lastivertsi, Historia, s. 137.

38 Por. Aristakes Lastivertsi, Historia, s. 138-140. 
może był to wpływ działań Izaaka, który zapewne przyjął taki plan walki z wrogiem. W tym kontekście Psellos wspomina w swojej Chronografii, że Izaak próbował zjednoczyć wschodnich i zachodnich barbarzyńców, którzy pod wrażeniem jego intelektu, przestali najeżdżać cesarstwo i poczęli szukać jego protekcji, pod którą mogliby się ukryć przed innymi zagrożeniami, zaś sam sułtan Partii zaczął się cofać i stał się niewidzialny ${ }^{39}$. Zdaje się taki plan działania również potwierdzać dobrze poinformowana Anna Komnena, która wspomina, że cesarz, nim wyruszył na zachód, spacyfikował barbarzyńców na wschodzie ${ }^{40}$.

Kilka miesięcy po przejęciu władzy Komnen przeszedł do reform finansów cesarstwa: ograniczył pensję płacone różnym dygnitarzom, wycofał też wiele chryzobulli nadającym wcześniej ziemie wchodzące w skład domeny cesarskiej ludziom świeckim i kościołowi ${ }^{41}$. To w rezultacie postawiło w opozycji do niego patriarchę, który pomógł mu uzyskać tron. Słusznie traktując postawę Cerulariusza jako zagrożenie dla swoich reform, cesarz pojmał go podczas wyjazdu patriarchy poza Konstantynopol, a następnie wraz z członkami jego rodziny skazał na wygnanie ${ }^{42}$. Mając czystą sytuację w stolicy, cesarz poprowadził w 1059 roku nad Dunajem wyprawę przeciwko Węgrom sprzymierzonym z Pieczyngami ${ }^{43}$. Po zaciągu wojska skierował się do Seredicy, gdzie pokazem siły zmusił Węgrów do zawarcia z nim sojuszu, a następnie uderzył na Pieczyngów, którym przewodził Selte - jego wojska rozbił w bitwie ${ }^{44}$. Na przeszko-

39 Mowa tutaj oczywiście o sułtanie Seldżuków. Ten fragment dzieła Psellosa nie jest do końca jasny i zrozumiały. Por. Michael Psellos, Chronographie II; VII 63, 122.

40 Por. Anna Comnena, Alexias, ed. D.R. Reinsch - A. Kambylis, CFHB 40/1, Berlin 2001, III 8, 7, 107.

41 Por. MichaelAttaliates, Historia XII 3-4, 108-112; Michael Psellos, Chronographie II; VII 60, 120; Skylitzes Continuatus, He synecheia 103, 19-104, 12 i 111, 16-17; Ioannes Zonaras, Epitome Historiarum XVIII 4, 12, 668; Mokhov, Voyennaya politika, s. 58; Kaldellis, Streams, s. 220.

42 Por. Michael Attaliates, Historia XII 5-8, 112-116; Michael Psellos, Chronographie II; VII 65, 123; Michael Glycas, Annales 16-20, 601; Skylitzes Continuatus, He synecheia 21, 104-14,105; Ioannes Zonaras, Epitome Historiarum XVIII 5, 4, 669; Mochov, Voyennaya politika, s. 59; Kaldellis, Streams, s. 221.

43 Na temat wcześniejszej polityki wojennej Bizancjum wobec Pieczyngów, por. A.S. Mochov, $K$ voprosu o vizantijskoj voennoj organizacii w period vojny z pečenegami 1046-1053 gg., ,Izvestija Uralskogo gosudarstnennogo universiteta” 39 (2005) s. 15-26.

44 Por. Michael Attaliates, Historia XII 13-14, 120-122; Michael Psellos, Chronographie II VII 67-68, 124-125; Anna Comnena, Alexias III 8, 6-7, 106-108; Michael Glycas, Annales, 8-20, 602; Ioannes Zonaras, Epitome Historiarum XVIII 6, 
dzie pełnemu pokonaniu koczowników stanęła we wrześniu 1059 roku pogoda. Ulewne deszcze wywołały powodzie, po których przyszły śnieżyce, co bardzo zaszkodziło oddziałom bizantyńskim, czego najlepszym dowodem jest padnięcie wszystkich koni i utrata całego zaopatrzenia ${ }^{45}$. $\mathrm{Na}$ dodatek w obozie Izaaka pojawiły się informacje o buncie w Azji Mniejszej. Dlatego cesarz powrócił do Konstantynopola, gdzie po jednym z jego polowań zachorował i następnie przekazał władzę po sobie Konstantynowi Dukasowi, jakoby zamiast bratu Janowi, co było też dziełem machinacji Michała Psellosa, a sam wstąpił do klasztoru Stoudios od którego zaczęła się jego kariera ${ }^{46}$.

Mając pełen obraz panowania Izaaka Komnena, możemy poszukać odpowiedzi na zadane na wstępie pytanie, czy cesarz miał i próbował realizować jakąś doktrynę wojenną. Rosyjski badacz wojskowości Bizancjum z XI wieku A.S. Mochov wszystkie decyzje Izaaka Komnena jako cesarza słusznie uważa za próbę naprawy zaniedbanych przez jego poprzedników sił zbrojnych cesarstwa, szczególnie tych operujących w części europejskiej imperium. Izaak swoją karierę zaczął przecież od służby w armii, której kształt i doktrynę wojskową stworzył Bazyli II: zatem składał się ona $\mathrm{z}$ dwóch armii polowych (wschodniej i zachodniej), w których ważną role odgrywały prowincjonalne tagmaty i oddziały najemników. Zdaniem Mochova czas rządów Izaaka to także początek zmiany pokoleniowej w kadrze dowódczej imperium, która swój finał znalazła w 1081 roku. Dokonali tego ludzie wywodzący się z arystokracji małoazjatyckiej, nie zaś z Konstantynopola. Odrzucono zatem wpływy elit stolicy, powracając do sytuacji z rządów Nicefora Fokasa czy Jana Tzimiskesa, gdy to wodzowie armii stali na czele państwa i osobiście prowadzili działania wojenne. Występując przeciwko Michałowi VI, Komnen miał pod swoją komendą najbardziej doświadczonych dowódców i oddziały wywodzące się z Azji

1-2, 671; Skylitzes Continuatus, He synecheia 106, 23-107, 4; Haldon, Warfare, s. 222; Kaldellis, Streams, s. 222.

45 Por. Michael Attaliates, Historia XII 14, 122; Michael Psellos, Chronographie II; VII 70, 127; Anna Comnena, Alexias III 8, 8, 108; Skylitzes Continuatus, He synecheia 109, 9-24; Ioannes Zonaras, Epitome Historiarum XVIII 6, 4, 671.

46 Por. Michael Attaliates, Historia XII 15-16, 125; Michael Psellos, Chronographie II; VII 73-92, 128-138; Skylitzes Continuatus, He synecheia 110, 17-19; Anna Comnena, Alexias III 8, 10, s. 109; Nicephore Bryennios, Historiarum libri quattuor I 1, 81, 7-83, 11-17; Ioannes Zonaras, Epitome Historiarum XVIII 7, 7-8, 673; A.S. Mochov, Komandnyi sostav vizantijskoi armii w pravlenie Konstantina X Duki (1059-1067 gg.), w: Vizantijskoe gosudarstvo w IV-XV vv. Centr i periferia. Tezisy dokladov XV Vserossijskoi naučnoi sessii vizantinistov, Barnaul 1998, s. 24-27; Kaldellis, Streams, s. 223. 
Mniejszej, wsparte siłami najemników ${ }^{47}$. Izaak po swojej koronacji tych ludzi obsadził na szczytach drabiny dowodzenia sił bizantyńskich, powierzając im kluczowe stanowiska na wschodzie: i tak Adrian Dalassen został duksem Antiochii, Aron duksem Mezopotamii, Katakolon Kekaumen duksem Kolonei i Chaldii, jeden z Dukasów - Jan - katepanem Edessy, stratopedrarchą wschodu zaś - Roman Skleros ${ }^{48}$. Decyzja o postawieniu na czele armii zachodu brata Izaaka też nie była błędem, ten bowiem jako kuropalata i domestyk według słów Bryenniosa dobrze dowodził oddziałami wywodzących się z trackich, ilyryjskich, macedońskich i bułgarskich kontyngentów ${ }^{49}$. Te działania naprawcze przerwała jednak późniejsza abdykacja Izaaka na korzyść Konstantyna Dukasa. Jak słusznie zauważył Mochov, również jedyna wyprawa wojenna Izaaka jako cesarza, zorganizowana przeciwko Węgrom i Pieczyngom, miała być testem dla tych oddziałów $z$ europejskiej części państwa ${ }^{50}$. Zdaniem tego badacza Izaak nie zdążył skończyć swoich reform państwa z racji swej choroby i późniejszej abdykacji ${ }^{51}$.

Izaak swoją doktrynę wojenną oparł na dwóch fundamentach, jakimi był podział na armie Wschodu i Zachodu, których podstawową siłę stanowić miały oddziały wywodzące się z danych prowincji, wsparte oddziałami najemnymi, a w doraźnych sytuacjach również gwardią cesarską. Taki układ wydaje się zrozumiały, ale był to zamierzony stan idealny, którego Izaakowi nie udało się niestety w czasie swego krótkiego panowania osiągnąć. Co więcej, mimo buńczucznych słów Psellosa o wpływie Izaaka na barbarzyńców nie udało się mu ich postępów zatrzymać na trwałe w Azji Mniejszej. To ten Komnen był współodpowiedzialny za wycofanie się z gry militarnej w bizantyńskiej Italii, gdyż w 1058 roku to on odwołał stamtąd Argyrosa, który tam organizował opór przeciwko Normanom ${ }^{52}$. Prowadzone przez Izaaka reformy fiskal-

47 Por. Wierzbiński, U boku bazyleusa, s. 234; Mokhov, Voyennaya politika, s. 55-57; A.S. Mochov, Vizantijjskaja armija v seredine-vtorojj polovine XI v. po dannym sfragistiki „Dokument. Arkhiv. Istorija. Sovremennost, Ekaterinburg” 8 (2007) s. 215 i 217.

48 Por. P. Lemerle, Cinq études sur le XIe siècle byzantin, Paris 1977, s. 39-44; W. Seibt, Die Skleroi. Eine prosopographisch-sigillographische Studie, Wien 1976, s. 76-85; Wierzbiński, U boku bazyleusa, s. 234; Mochov, Voyennaya politika, s. 56.

49 Por. Nicephore Bryennios, Historiarum libri quattuor I 1, 79, 7-19; Wierzbiński, U boku bazyleusa, s. 234; Mochov, Voyennaya politika, s. 57.

50 Por. Mochov, Voyennaya politika, s. 57.

51 Por. Mochov, Voyennaya politika, s. 59.

52 Por. Antiche cronache di Terra di Barii, ed. G. Cioffari - R.L. Tateo, Bari 1991, s. 160; Bonarek, Bizancjum w dobie, s. 65. 
ne miały naprawić sytuację, w której znalazło się Bizancjum po śmierci jego wielkiego patrona, Bazylego II. Na tym polu szczególne znaczenie ma numizmatyka. Już w 1057 roku po sukcesie swojej uzurpacji Izaak Komnen bił nowe monety przedstawiające go z mieczem ${ }^{53}$. Takimi słowy opisują tę edycję monet bizantyńscy dziejopisowie Glykas, Zonaras, czy Skylitzes Continuatus. My dzięki zachowanym do dzisiaj numizmatom jesteśmy w stanie powiedzieć nieco więcej na ich temat. Mianowicie dysponujemy do dziś dwoma edycjami histamenonów i jedną tetearteronu, które są ważne z punktu widzenia moich rozważań. Pierwszy z histamenonów na rewersie przestawia Izaaka ubranego w zbroje łuskową, trzymającego w prawej ręce nagi miecz, lewą zaś wspartego na pochwie ${ }^{54}$. Drugi jest równie interesujący, Izaak bowiem stoi przodem ubrany w koronę i w strój wojskowy, trzymając labarum w prawej ręce oraz ma spoczywającą lewą rękę na mieczu w pochwie ${ }^{55}$. Tetearteron przedstawia zaś Izaaka stojącego przodem, w koronie i zbroi, który trzyma krzyż na kuli ziemskiej i schowany w pochwie miecz oparty na ziemi ${ }^{56}$. Wspomniany wyżej drugi z histamenonów i owy tetearteron nawiązują do srebrnych miliaresionów Konstantyna IX Monomacha, na których został przedstawiony on podobnie, z tym że zamiast labarum, czy kuli, w swojej prawej ręce dzierży długi krzyż ${ }^{57}$. Jest to ciekawy numizmat, Konstantyn IX bowiem nie był wojskowym, lecz przedstawicielem arystokracji stolicy, a starał się tą edycją monet ukazać prestiż militarny swojej władzy. Prócz Izaaka do tego typu przedstawienia osoby cesarza nawiązał w swoich miliaresionach Michał VII Dukas (1071-1078) czy Nicefor Botaniata (1078-1081) ${ }^{58}$. Występowanie nagiego miecza trzymanego przez Izaaka na pierwszym $z$ histamenonów było wyrazem mniemania cesarza, że zawdzięcza on tron swoim zdolnościom wojskowym, nie zaś woli Bożej ${ }^{59}$. Do tej edycji monet nawią-

53 Por. Skylitzes Continuatus, He synecheia 3-8, 103; Michael Glycas, Annales 1-8, 601; Ioannes Zonaras, Epitome Historiarum XVIII 4, 8, 667; Stănescu, Les réformes, s. 42.

54 Por. A.R. Bellinger, Catalogue of the Byzantine Coins in the Dumbarton Oaks Collection and in the Whittemore Collection, Leo III to Nicephorus III, 717-1081, Washington 1977, s. 762, nr 2.

55 Por. Bellinger, Catalogue of the Byzantine, s. 761, nr 1.

56 Por. Bellinger, Catalogue of the Byzantine, s. 763.

57 Por. P. Grierson, Catalogue of the Byzantine Coins in the Dumbarton Oaks Collection and in the Whittemore Collection, Volume 3 Leo III to Nicephorus III, 717-1081, t. 2, Washington 1973, s. 745.

58 Por. Grierson, Catalogue of the Byzantine, s. 801, 811 i 830.

59 Por. Bellinger, Catalogue of the Byzantine, s. 760. 
zują również cesarskie pieczęcie, na których przedstawiony Izaak nosi koronę z krzyżem, pendilia, ubrany jest w zbroję, pokazany jest z podniesionym mieczem $\mathrm{w}$ prawej ręce $\mathrm{i}$ globusem w lewej ${ }^{60}$.

Owe monety i pieczęcie pozostałe po panowaniu tego basileusa są wyraźnym dowodem na próbę odbudowania propagandy prestiżu bizantyńskiego oręża i majestatu władzy cesarskiej. Wyraźnie nawiązywał nimi Izaak do swego wielkiego poprzednika i protektora Bazylego II, który w podobnym stylu jak Komnen na monetach przedstawiony jest w wykonanym dla niego menologium, jak i do Konstantyna IX i jego miliaresionów ${ }^{61}$. Dobrze oddaje to również doktrynę wojenną stosowaną przez Izaaka Komnena przez całe jego dorosłe życie. Nie był on bowiem w jakiś zasadniczy sposób kreatorem nowego punktu widzenia na wojskowość bizantyńską tego okresu, a raczej kontynuował on dzieło Bazylego II, Jana Tzimiskesa i Nicefora II Fokasa ${ }^{62}$. Opierał się w nim na swojej rodzinie i grupie osób z nim związanych doświadczeniem ze służby w armii, a przy tym wywodzących się z Azji Mniejszej. To zapewne oni tworzyli rdzeń jego doktryny wojskowej, jak również mieli ją realizować. Było to niezwykle trudne zadanie w geopolitycznym położeniu Bizancjum początków drugiej połowy XI wieku, szczególnie wobec parcia koczowników na granice imperium w Europie i Azji, jak również problemów z inflacją oraz obniżeniem się wartości złotych monet. Na pełną realizację planów militarnych i rozwiniecie owej doktryny wojennej zabrakło Izaakowi zwyczajnie czasu.

\section{Isaac I Komnenos (1007-1060). Army Chief, Rebel, Emperor - in Search of his Military Doctrine?}

(summary)

Isaac Komnenos (1007-1060) was the first representative of his family to sit on the imperial throne in Constantinople. This man raised by Emperor Basil II (976-1025), during his unusually short reign, attempted to repair the errors of his predecessors, who at the end of

60 Por. J.W. Nesbitt, Catalogue of Byzantine Seals at Dumbarton Oaks and in the Fogg Museum of Art, t. 6, Washington 2009, s. 128-129, nr 76.1, nr 76.2 i nr 76.3.

${ }_{61}$ Por. N. Patterson Ševčenko, Menologion of Basil II, w: Oxford Dictionary of Byzantium, t. 2, ed. A. Kazhdan, Oxford 1991, s. 1341-1342; Grierson, Catalogue of the Byzantine, s. 745 i 759.

62 Na temat kontynuacji polityki militarnej Bizancjum prowadzonej przez Bazylego II, a kontynuowanej do pewnego stopnia przez Komnenów i Dukasów, por. J.-Cl. Cheynet, La politique militaire Byzantine de Basile II à Alexis Comnène, ZRVI 29-30 (1991) s. 63-74. 
the Macedonian dynasty made the country of the Romans militarily weak. This would not have been possible without military education, extended to empirical experience that Isaac acquired during his years of service at various levels of the Byzantine army. Is it possible, then, to outline the war doctrine that guided this man at various stages of his service, and whose end was the imperial purple? The coins and seals remaining after the reign of this basileus are clear evidence of an attempt to rebuild the propaganda of the prestige of Byzantine weapons and the majesty of imperial power. Isaac referred to his great predecessor and protector Basil II, who in a similar style to Komnenos on coins is depicted in the Menologium made for him, as well as modeled on the milliaresions of Constantine IX. It also reflects well the war doctrine that Isaac Komnenos used throughout his adult life. He was not in any way a creator of a new point of view on the Byzantine military of that period, but rather he continued the work of Basil II, John Tzimiskes and Nicephorus II Phocas. It was a difficult task, in the geopolitical position of Byzantium at the beginning of the second half of the 11th century, especially because of the push of nomads to the borders of the empire in Europe and Asia. Unfortunately, Isaac did not have enough time to complete it.

Keywords: Byzantium; Isaac Komnenos; Seljuk Turks; Pechengs; Komnenos clan; Iberia; Byzantine Army

\section{Izaak I Komnen (1007-1060). Wódz, buntownik, cesarz - w poszukiwaniu jego doktryny wojennej?}

(streszczenie)

Izaak Komnen (1007-1060) był pierwszym przedstawicielem swojej rodziny, który zasiadł na tronie cesarskim w Konstantynopolu. Ten wychowany przez cesarza Bazylego II (976-1025) człowiek podczas niezwykle krótkiego panowania próbował naprawić błędy swoich poprzedników, którzy pod koniec dynastii macedońskiej osłabili kraj Rzymian pod względem militarnym. Nie byłoby to możliwe bez edukacji wojskowej, rozszerzonej poprzez doświadczenie empiryczne, które Izaak nabył podczas lat służby na różnych poziomach armii cesarstwa. Czy jest zatem możliwe nakreślenie doktryny wojennej, która kierowała tym człowiekiem na różnych etapach jego służby wojskowej, a której końcem była imperialna purpura? Monety i pieczęcie pozostałe po panowaniu tego basileusa są wyraźnym dowodem na próbę odbudowy prestiżu bizantyńskiej broni i majestatu władzy cesarskiej. Izaak odniósł się w nich do pamięci swojego wielkiego poprzednika i wychowawcy Bazylego II, który w stylu podobnym do wykorzystanego przez Komnena na monetach jest przedstawiony w stworzonym dla niego menologium, jak również wzorował się na miliaresionach Konstantyna IX. Odzwierciedla to również doktrynę wojenną, której był wierny Izaak Komnen przez całe swoje dorosłe życie. Nie był w żaden sposób twórcą nowego punktu widzenia na bizantyńską armię tamtego okresu, ale raczej kontynuował dzieło Bazylego II, Jana Tzimiskesa i Nicefora II Fokasa. Było to trudne zadanie wobec geopolitycznej pozycji Bizancjum na początku drugiej połowy XI wieku, zwłaszcza z powodu parcia różnego rodzaju koczowników na granice imperium w Europie oraz Azji. Niestety, Izaak nie miał dość czasu, aby się wywiązać z założonego sobie zadania. 
Słowa kluczowe: Bizancjum; Izaak Komnen; Seldżuccy; Pieczyngowie; Komenowie; Iberia; bizantyńska armia

\section{Bibliografia}

\section{Źródła}

Anna Comnena, Alexias, ed. D.R. Reinsch - A. Kambylis, CFHB 40/1, Berlin 2001. Antiche cronache di Terra di Barii, ed. G. Cioffari - R.L. Tateo, Bari 1991. Aristakes Lastivertsi, Historia, ed. R. Bedrosian, New York 1985. Antiche cronache di Terra di Barii, ed. G. Cioffari - R.L. Tateo, Bari 1991. Constantinus Manasses, Breviarium chronicum, t. 1-2, ed. O. Lampsidis, Athens 1996. Ioannes Scylitzes, Synopsis Historiarum, ed. I. Thurn, Berlin - New York 1973.

Ioannes Scylitzes, Epitome Historiarum libri XIII-XVIII, ed. T. Buttner-Wobst, Corpus scriptorum historiae Byzantinae 49, Leipzig 1897.

Matteos Uṛhayetsi, Zhamanakagrut'iwn-The Chronik of Matthew of Edessa, ed. A.E. Dostourian, New York 1993.

Michael Attaliates, Historia, ed. A. Kaldellis - D. Krallis, London 2012.

Michael Glycas, Annales, ed. I. Bekker, Bonn 1836.

Michael Psellos, Chronographie (976-1077), t. 1-2, ed. E. Renauld, Paris 1928.

Nicephore Bryennios, Historiarum libri quattuor, ed. P. Gautier, Corpus Fontium Historiae Byzantinae 9, Brussels 1975.

Skylitzes Continuatus, He synecheia tes Chronographias tou Ioannou Skylitse, ed. E.Th. Tsolakes, Thessalonike 1968.

\section{Opracowania}

Angold M., The Byzantine Empire 1025-1204. A political history, London 1984.

Bellinger A.R., Catalogue of the Byzantine Coins in the Dumbarton Oaks Collection and in the Whittemore Collection, Leo III to Nicephorus III, 717-1081, Washington 1973.

Böhm M., The Military Policy of Isaac Komnenos at the time of battle of Petroe (1057), „Open Political Science” 1 (2018) s. 136-142.

Bonarek J., Bizancjum w dobie bitwy pod Mantzikert, Kraków 2011.

Cheynet J.-Cl., L'iconographie des sceaux des Comnènes, w: Siegel und Siegler: Akten des 8. Internationalen Symposiums für Byzantinische Sigillographie, ed. Cl. Ludwig, Frankfurt a. M. 2005, s. 53-67.

Cheynet J.-Cl., La politique militaire Byzantine de Basile II à Alexis Comnène, ZRVI 29-30 (1991) s. 63-74.

Cheynet J.-Cl., Par St Georges, par St Michel, „Travaux et Mémoires” 14 (2002) s. 115-134.

Cheynet J.-Cl., Pouvoir et contestations à Byzance (963-1210), Paris 1996. 
Cutler A. - Brand C.M., Isaac I Komnenos, w: Oxford Dictionary of Byzantium, t. 2, ed. A. Kazhdan, Oxford 1991, s. 1011-1012.

Dudek J., Pęknięte zwierciadło - kryzys i odbudowa wizerunku władcy bizantyńskiego od 1056 do ok. 1095 roku, Zielona Góra 2009.

Encyklopedia PWN, w: https://encyklopedia.pwn.pl/haslo/doktryna-wojenna;3893480. html (dostęp 10.10.2019).

Grierson P., Catalogue of the Byzantine Coins in the Dumbarton Oaks Collection and in the Whittemore Collection, Volume 3 Leo III to Nicephorus III, 717-1081, t. 1-2, Washington 1973.

Haldon J., Warfare, State and Society in the Byzantine World, 565-1204, London 2003.

Inoue K., The Rebellion of Isaakios Komnenos and the Provincial Aristocratic Oikoi, „Byzantinoslavica” 54 (1993) s. 268-278.

Kaldellis A., Streams of Gold, Rivers of Blood: The Rise and Fall of Byzantium, 955 A.D. to the First Crusade, Oxford 2017.

Kekaumenos, Sovety i rasskazy Kekavmena: Sočinenie vizantijskogo polkovodca XI veka, ed. G.G. Litavrin, Moscow 2003.

Krsmanović B., Uspon vojnog plemstva u Vizantii XI veka, Beograd 2001.

Lemerle P., Cinq études sur le XIe siècle byzantin, Paris 1977.

Mochov A.S., Vizantijjskaja armija v seredine - vtorojj polovine XI v. po dannym sfragistiki, „Dokument. Arkhiv. Istorija. Sovremennost, Ekaterinburg” 8 (2007) s. 212-218.

Mochov A.S., Voyennaya politika Isaaka I Komnina, „Nauchnyye vedomosti Belgorodskogo gosudarstvennogo universiteta. Ser., Istoriya. Ekonomika. Politologiya, Informatika" 120 (2012) s. 52-60.

Mochov A.S., $K$ voprosu o vizantijskoj voennoj organizacii w period vojny z pečenegami 1046-1053 gg., „Izvestija Uralskogo gosudarstnennogo universiteta” 39 (2005) s. 15-26.

Mochov A.S., Komandnyi sostav vizantijskoi armii v 1055-1057 gg., ADSV 33 (2002) s. 109-122.

Mochov A.S., Komandnyi sostav vizantijskoi armii w pravlenie Konstantina X Duki (1059-1067 gg.), w: Vizantijskoe gosudarstvo w IV-XV vv. Centr i periferia. Tezisy dokladov XV Vserossijskoi naučnoi sessii vizantinistov, Barnaul 1998, s. 24-27.

Nesbitt J.W., Catalogue of Byzantine Seals at Dumbarton Oaks and in the Fogg Museum of Art, t. 6, Washington 2009.

Nezu Y., The Revolt of Isaakios Komnenos: Reconsideration, „Orient” 42 (2006) s. 41-60.

Patterson Ševčenko N, Menologion of Basil II, w: Oxford Dictionary of Byzantium, t. 2, ed. A. Kazhdan, Oxford 1991, s. 1341-1342.

Šandrovskaja V.S., Isaak Komnin - pravitel' Iverii, „Istoriko-filologičeskij Zurnal” 4 (1983) s. 110-117.

Seibt W., Die Skleroi. Eine prosopographisch-sigillographische Studie, Wien 1976.

Shepard J., Isaac Comnenus Coronation Day, ,Byzantinoslavica” 38 (1977) s. 22-31.

Stănescu E., Les réformes d'Isaac Comnène, RESEE 4 (1966) s. 35-69. 
Stanković V., Komnini u Carigradu (1057-1185). Evolucija jedne vladarske porodice, Beograd 2006.

Treadgold W., Byzantium and Its Army, 284-1081, Stanford 1995.

Varzos K., I Genealogía ton Komninón, t. A, Thessaloniki 1984.

Wierzbiński S., U boku bazyleusa. Frankowie $i$ Waregowie $w$ cesarstwie bizantyńskim w XI w., Łódź 2019. 